\title{
The Worst of the Worst: Celebrating Twenty Years of the Worst Serial Title Change of the Year Award
}

\section{Margaret Mering and Pamela Simpson}

\begin{abstract}
Serials librarians untangle some of the most complicated bibliographic control problems. The year 1994 marked the twentieth anniversary of the best known attempt at consciousness raising: the Worst Serial Title Change of the Year Award. Among significant efforts to lower the number of possible title changes was the implementation of the second edition of the AngloAmerican Cataloguing Rules. Librarians continue to work on initiatives to improve communication with publishers and to increase awareness of problems caused by title changes. While much work has been done to decrease the number of new bibliographic records for title changes, there remains room for improvement and further streamlining. We propose that the United States Newspaper Program's cataloging guideline-which specifies that if a title change lasts for less than one year and then reverts back to the previous title, the change does not require a new record-be extended to all serials. In addition to the changes proposed above, more empirical research is needed to aid serial catalogers in handling title changes.
\end{abstract}

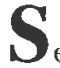
gling some of the most complicated bibliographic control problems in the library world. Their work requires analyzing new publications and answering many difficult questions: Is this a monograph or a serial? Should the supplement have its own record? Should each supplement be treated as a monograph? Is this a minor variation in title or an actual title change? Serials librarians are justifiably proud of their expertise, and most of them do in fact enjoy problem solving. Occasionally, however, they wonder whether all these changes are necessary. At times it seems that publishers are united in a conspiracy against them, or, at the very least, that title changes like the one from Animal Nutrition \& Health to Animal Health \& Nutrition are capricious and arbitrary. Historically, serials librarians have tried to modify catalog rules to avoid title changes and to communicate with publishers about the effect title changes have on work in libraries. The year 1994 marked the twentieth anniversary of the best known attempt at

Margaret Mering is Principal Serials Cataloger at the University of Nebraska-Lincoln and a past member of the Worst Serials Title Change of the Year Award Committee (mvm@unllib.unl.edu); Pamela Simpson is Serials Cataloging Librarian at Pennsylvania State University (pse@psulias.psu.edu). Manuscript received March 16, 1995; revised October 11, 1995; accepted for publication November 1, 1995. 
consciousness raising: the Worst Serial Title Change of the Year Award.

Librarians United to Fight Costly, Silly, Unnecessary Serial Title Changes (LUTFCSUSTC), pronounced loot-fi-sustic (Title Varies, Dec. 1973, 3), began the tradition of giving this award. At the fall 1973 Michigan Library Association Conference, LUTFCSUSTC was formed with the goal of educating publishers in a humorous way about the processing costs and other problems associated with title changes. They soon rallied serials librarians across the United States to join their cause. Under the leadership of David C. Taylor, serials librarian at Michigan State University and later undergraduate librarian at the University of North Carolina at Chapel Hill, the group published its newsletter, Title Varies, from 1973 to 1980. It alerted its readers to "awful" title changes, revisions to catalog rules affecting title changes, ways of educating publishers about title changes, and other problems associated with the handling of serial publications.

In July 1974, at the business meeting of the American Library Association's (ALA) Resources \& Technical Services Division (now known as ALCTS, the Association for Library Collections \& Technical Services), LUTFCSUSTC began the tradition of awarding Worst Serial Title Change of the Year Awards. Since 1983, a committee of the association's Serials Section has presented these awards. According to this twenty-year-old tradition, approximately ten publishers are recognized for title changes they have made during the past year. Awards often go to publishers whose serials seem to have changed for no apparent reason or that have simply shuffled the order of the words in the title. Serials that repeatedly change their titles are also good candidates for awards. A special category known as the Snake in the Grass or the Et Tu Brute award is reserved for library science publishers. One of the ten nominated publishers receives the dubious honor of having the very worst title change of the year (see appendix A).

Each year, calls for nominations appear in the ALCTS Newsletter, Cataloging \& Classification Quarterly, the NASSIG Newsletter, Serials Review, and
Technical Trends. Several times a year requests for nominations are sent to the electronic discussion groups AUTOCAT and SERIALST. The deadline for submitting nominations is a month or two before the ALA's Annual Conference. The Worst Serial Title Change of the Year Committee evaluates the nominations and assigns awards to worthy title changes. The awards are presented at the annual meeting of the Association of Library Collections \& Technical Services (ALCTS), and notices are published in several library science publications.

Publishers are not normally notified of their awards. However, in 1990, ALCTS executive director Karen Muller personally accepted an award for the title change RTSD Newsletter to ALCTS Newsletter. Also that year, the award notices were published for the first and only time in a nonlibrary publication, the Chronicle of Higher Education.

Since the formation of LUTFCSUSTC, one of the most significant efforts in lowering the number of possible title changes was the implementation of the second edition of the Anglo-American Cataloguing Rules' (AACR2) rule 21.1B2. According to this rule, serials are entered under corporate body only if the work is about the corporate body itself or its activities (AACR2 1978, 285-86). This rule greatly limits the number of titles that can be entered under corporate body. When a corporate body changes its name, only those serials actually entered under the body and those whose uniform titles have been qualified by the name of the body require a new bibliographic record.

Another attempt to reduce the number of title changes was a 1983 change in the interpretation of rule $25.5 \mathrm{~B}$. Place of publication became the first choice of qualifier for serial uniform titles rather than corporate body. When a place of publication is used as the uniform title qualifier and the place of publication changes, a new record is not created. Opponents of this rule interpretation argue that place of publication is often not as meaningful or useful as a corporate body might be to patrons or staff attempting to find serials in library catalogs (Turitz 1990, 86-87). 
What does not constitute a title change has been clarified and expanded over the past twenty years. The wider use of the OCLC Online Computer Library Center, Inc., and other bibliographic utilities brought a need for more cooperative, standardized cataloging and thus the increased need for interpreting and revising cataloging rules. The first edition of the AACR states that changes in title "so slight that they do not affect the location of the title in an alphabetical file, or conceal the identification of the parts" are noted in a general statement such as "Title varies slightly" or "Subtitle varies" (AACR 1967, 239). Later rule interpretations and cataloging codes have included the following much more specific instances of what will not be considered a title change (AACR2R 1988, 314-15):

- Changes in the representation of words;

- Additions, deletions, or changes after the fifth word that do not change the meaning of a title;

- Addition or deletion of articles, prepositions, or conjunctions;

- Addition or deletion of the issuing body at the end of the title; and

- Changes in the punctuation of the title. Full-length articles about serial title changes first appeared in library literature in the 1970s and have continued to appear during the last twenty years. Several of these articles expressed support for David Taylor and his work. Their authors attempted to persuade publishers of the trouble and expense title changes cause for libraries. Kuhns, writing in 1976, pleaded with publishers to think long and hard before changing a title, and asked at the very least that publishers notify subscribers if they must make a change (Kuhns 1976-77). She mentioned Title Varies, as did Gorman in an article the previous year, as being one of the few publications in the library field attempting to tackle these problems (Gorman 1975, 305). Robertson set out to enlighten publishers about the complex record keeping required for serials and the havoc wreaked by title changes. He offered examples of silly title changes, citing a letter to Title Varies as evidence that LUTFCSUSTC was making an impact on the publishing community (Robertson 1979, 418).

Foggin, on the other hand, argued that title changes are usually justified, at least for the publisher, and that the costs for libraries are not really as high as others have claimed. She portrayed librarians as suppliers to the readers, who are the real customers, suggesting that we should perhaps not presume to tell publishers how to manage their product (Foggin 1992). It could also be argued, however, that libraries are themselves important customers for publishers, and that librarians have more opportunities to work with readers as they search for and use serial publications than do most publishers.

Several authors describe studies in which they examined the rate and impact of title changes. Charbonneau looked at OCLC records for about 1,250 titles. He divided the number of title changes he found in these records by the number of years the serials had been published and came up with an approximate rate of change for all serials. This formula proved relatively accurate for the science journals in his sample as well as those in other fields of study. He christened his formula Taylor's Constant, in honor of David Taylor (Charbonneau 1982). A few years later, Khosh-khui took a smaller sample of OCLC serial records and correlated the rate of change with other variables, such as language, place of publication, and subject matter. He found that serials published by governmental bodies, those in French or Polish, and those in the sciences changed more often than others (Khosh-khui 1986, 91). Roberts, Vidor, and Bailey determined cost and time required for recording title changes in their library (Roberts, Vidor, and Bailey 198687). Afes and Wrynn carried out a twopart study of biomedical titles that was designed to establish the effect of title changes on medical libraries and the percentage of title changes that appeared to be justified. They found that two-thirds of their sample had changed title due to a change in scope or in the terminology used in the field. They were unable to ascertain a clear reason for the remaining title changes. 
Another hot topic in the literature continues to be the suitability of using successive entry cataloging in an online integrated library environment. Successive entry cataloging is the current standard for handling title changes. It calls for a separate bibliographic record for each title change of a serial. In the late 1980s, technical services librarians at Northwestern University Library became well known for departing from using successive entry cataloging exclusively. They established guidelines for specific categories of title changes to be handled by latest entry cataloging, the convention of recording the latest title as the main entry and listing earlier titles in a note field (Case et al. 1988, 41). Cole suggests the alternative of having the earliest title as the main entry and listing later titles in a note field (Cole 1986, 5). Those advocating the use of earliest or latest entry cataloging believe these methods provide more efficient and economical means of handling title changes than does successive entry cataloging. They point out that these methods keep all bibliographic, order-holding, and circulation information for a serial and its title changes available with one search. In other words, either convention eliminates the need to consult two or more records to gather information on each title change. The use of one record also saves computer storage space, as well as searching and retrieval time. These advantages benefit libraries, their personnel, and patrons (André et al. 1986, 4243).

Today, librarians continue to work on several initiatives to improve communication with publishers and to increase awareness of problems caused by title changes. One example is the North American Serials Interest Group's Cataloging Discussion Group, which offers a forum for serials librarians, vendors, and publishers to discuss issues surrounding title changes and other related issues. Also, the ALCTS Serials Section has published a 1995 brochure called "What's in a Name?" It provides guidelines for periodical publications based on ANSI Standard Z39.1, American National Standard for Periodicals Format and Arrangement.
The brochure includes information on what constitutes a title change and the problems that such changes cause for libraries, as well as instructions for obtaining an International Standard Serial Number (ISSN). Publishers often contact a national ISSN center before a new serial appears, or before a title change occurs. More than fifty-five of these centers exist worldwide, and they make an effort to communicate with publishers about the importance of stable titles and coherent numbering, and about the problems that nonstandard practices cause for libraries. Of course, some publishers do not contact ISSN centers, and they are often the ones who are unaware of the consequences their decisions have for libraries.

Another excellent example of librarians working directly with publishers to reduce unnecessary title changes is the recent development of title guidelines by the Institute of Electrical and Electronic Engineers (IEEE). IEEE conducted a survey of librarians and found that IEEE publications were notoriously difficult to catalog and retrieve. An internal IEEE task force worked with Peter Graham of Rutgers University, Ilona Bicsak of Columbia University, Regina Reynolds of the Library of Congress, and other librarians to develop guidelines for the various groups within IEEE who publish proceedings (IEEE 1995).

While much work has been done to decrease the number of new bibliographic records for title changes, there remains room for improvement and further streamlining. Crystal Graham has said that, while the Worst Serial Title Change of the Year Award is often deserved, "in other instances, the award should probably go to AACR2 for requiring silly, costly, unnecessary, confusing successive records" (Graham 1995, 10). She cites the example of the Atlantic Monthly changing its title back and forth between Atlantic and Atlantic Monthly, and asks whether better bibliographic access is provided by the existence of five separate records for this serial.

Although AACR2 reflects attempts to improve the situation as mentioned earlier, in some cases the insistence on suc- 
cessive entry for most changes has resulted in databases that are cluttered with unnecessary successive records. Cataloging rules do not currently provide enough instruction to delineate between trivial title changes and more significant ones. The authors believe that guidelines should be developed and concur with Graham's suggestion that catalogers treat minor changes as variant titles and make added entries for them instead of creating new records. The definition of a trivial change versus a significant one should allow room for catalogers' judgment. However, such changes as adding or deleting words denoting frequency, adding or deleting generic words such as magazine or journal, and simply changing the order of words within a title are all changes that could be added to the list of what is not considered a title change.

We propose that the United States Newspaper Program's cataloging guideline-which specifies that if a title change lasts for less than one year and then reverts back to the previous title, the change does not require a new record-be extended to all serials (Butler 1990, 160). The authors further suggest a Library of Congress Rule Interpretation to reverse the dictum of rule 21.183 , "if in doubt, consider the title proper to have changed." Another area the authors would like reviewed is the choice of qualifiers for uniform titles. Havens believes uniform titles should be eliminated altogether, and offers several alternatives for providing access to generic titles (Havens 1987, 68). Turitz feels that users are not well served by the use of place of publication as the first choice of qualifier. He points out that corporate bodies as qualifier of uniform titles are often more meaningful to users (Turitz 1990, 87). Havens and Turitz suggest that instead of creating a new successive record when a corporate body qualifier of a uniform title changes, catalogers could change the heading to the new form and add an issuing body note and an added entry for the old form of heading.

In addition to the changes proposed above, more empirical research is needed to aid serial catalogers in handling title changes. For instance, what effect does successive entry cataloging have on library catalog users? Has the rate of title changes changed in the past twenty years? How does the rate differ by discipline, and what are the implications for different types of libraries? As library budgets continue to decrease and as user expectations rise, librarians need to look at all cataloging practices with a critical eye. They need to verify that the practices are efficient, practical, and serve users well. They should continue to work with the publishing community to ensure their understanding of the implications of title changes. Nevertheless, as long as serials are published, title changes will continue to occur, as will a desire to alleviate frustrations by laughing at those changes that are costly, silly, and unnecessary. Hopefully, the Worst Serial Title Change of the Year Award will be around to fill that need.

\section{WORKS CTTED}

Afes, Van B., and Paul E. Wrynn. 1993. Biomedical journal title changes: Reasons, trends, and impact. Bulletin of the Medical Library Association 81: 48-53.

ALCTS. 1990. Activities at the annual ALCTS membership meeting. ALCTS newsletter 1: 59-62.

ALCTS. 1991. ALCTS awards presentations. ALCTS newsletter 2: 59-64.

ALCTS. 1992. Worst serial title change of year awards, 1992. ALCTS newsletter 3: 62-64.

ALCTS. 1995. What's in a name? Presentation guidelines for serial publications. Chicago: Serials Section, Association for Library Collections \& Technical Services, ALA.

André, Priscilla W., Elisabeth Janakiev, Mary M. Case, and Kevin Randall. 1986. Serials control in an online integrated system: Can latest entry cataloging help? Cataloging b classification quarterly 7 , no. 2: 39-53.

Anglo-American cataloguing rules. 1967. North American text. Chicago: ALA.

Anglo-American cataloguing rules. 1978. $2 \mathrm{~d}$ ed. Chicago: ALA.

Anglo-American cataloguing rules. $1988.2 \mathrm{~d}$ ed., 1988 rev. Chicago: ALA.

Butler, Todd. 1990. The newspaper cataloging and union listing manual. Washington, D.C.: Cataloging Distribution Service, Library of Congress.

Case, Mary M., Elisabeth Janakiev, Kevin M Randall, and Bradley D. Carrington. 1988. 


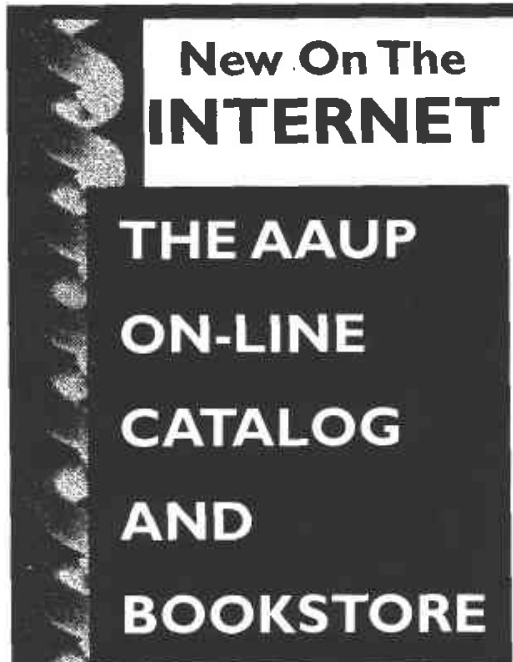

\section{A COMPREHENSIVE ELECTRONIC RESOURCE}

of scholarly publications from the members of the Association of American University Presses

\section{FREE ACCESS}

to bibliographic information on more than 65,000 titles

\section{USER-FRIENDLY PROCEDURES}

using author, title, keywords, subject category, or publisher name

\section{EASY ORDERING INFORMATION}

Using customized order forms from participating presses

The Catalog contains fully searchable bibliographic data and descriptive text from more than 50 scholarly publishers.

\section{Accessing the Catalog via WWW or Gopher:}

http:I/aaup.princeton.edu http:llpress-gopher.uchicago.edu

The Association of American University Presses, Inc 584 Broadway - Suite 4:0 - New York NY $100 \mid 2$
Rules for latest entry cataloging: Northwestern University Library supplement to AACR2. Cataloging \& classification quarterly 9, no. 2: 41-54.

Charbonneau, Gary. 1982. Taylor's constant. Serials librarian 7 , no, 1: 19-22.

Cole, Jim E. 1986. The first shall be last: Earliest entry cataloging. Serials librarian 11, no. 1: 5-13

Foggin, Carol Monroe. 1992. Title changes: Another view. Serials librarian 23, nos. 1/2: 71-83.

Gordon, Anne. 1994. 1994 Worst Serial Title Change Awards. ALCTS newsletter 5, no. 5: 72

Gorman, Michael. 1975. The current state of standardization in the cataloging of serials. Library resources \& technical services 19 : 301-13.

Graham, Crystal. 1995. What's wrong with AACR2: A serials perspective. Paper presented at the ALCTS AACR2000 preconference, June 22, 1995, in Chicago.

Havens, Carolyn. 1987. Proposed changes in the cataloging of serials with generic and uniform titles. Serials librarian 13, no. 4: $59-60$.

IEEE. 1995. IEEE implements new titling plan for conference proceedings. IEEE publications bulletin 26, no. 2: 1-2.

Khosh-khui, A. (Sam). 1986. Title changes and variations in other components of serials. Serials librarian 11, no. 2: 83-92.

Kuhns, Kathleen. 1976-77. Serials librarians and their discontents. Serials librarian 1, no. 2: 173-81.

O'Neill, Rosanna M. 1993. Worst serial title change awards. ALCTS newsletter 4: 80.

Roberts, Constance F., Ann B. Vidor, and Dorothy C. Bailey. 1986-87. Time and cost analysis of title changes in serials. Serials librarian 11, nos. 3/4: 137-42.

Robertson, Howard W. 1979. What every serials publisher should know about unnecessary title changes. Serials librarian 3, no. 4: 417-22.

RTSD, 1981. Worst serial title changes announced. RTSD newsletter 6: 54 .

RTSD. 1988. Reports of committee and discussion groups. RTSD newsletter 13: 4253.

RTSD. 1989. Reports of committee and discussion groups. RTSD newsletter 14: 3946.

Title Varies. 1973-1980.

Turitz, Mitch L. 1990. Uniform titles for serials: The controversy continues. Serials review 16, no. 1: 85-89, 98. 


\section{APPENDIX A}

Below is a list of the winners of the Worst Serial Title Change of the Year Awards over the past twenty years, together with excerpts of the accompanying citation.

1974-In recognition of their meaningless title changing and meritorious bibliographic obfuscation, Librarians United to Fight Costly, Silly, Unnecessary Serial Title Change awards Williams and Wilkins with Worst Serial Title Change of the Year, 1973, for the ridiculous change International Journal of Obstetrics and Gynecology to International Joumal of Gynecology and Obstetrics (Title Varies, Sept. 1974, 36).

1975 - . . . and the winner is, Martin Psychiatric Research, Inc., for the change: Corrective and Social Psychiatry to Journal of Applied Behavior Technology, Method, and Therapy (Title Varies, July 1975, 28)!

1976 - The contest was fierce, but in the end the library profession's own worst title change prevailed as the champion worst. The Mountain/Plain Library Association Quarterly became the MPLA Newsletter in 1975 and continued to demonstrate that no one is more insensitive to library problems than librarians (Title Varies, Sept. $1976,36)$.

1977-This lovely engraved silver platter is awarded, emblematic of the second worst serial title change award for 1976 , to the Economist Intelligence Unit, Ltd. of London, for its changes of the $Q E R$... to Quarterly Economic Review of... This is a set of approximately one hundred related titles, each a separate periodical with the title originally, Quarterly Economic Review: Italy, Quarterly Economic Review: Spain, and so on. In 1975, they changed to QER: Italy, QER: Spain, etc. In 1976, they all changed, every last one of them, to Quarterly Economic Review of Italy, Quarterly Economic Review of Spain and so forth. In recognition of the cost to libraries and the total uselessness of these changes, we are naming $Q E R$ not only second worst, but third worst and fourth worst-in fact one hundred title change awards, including worst of all (Title Varies, Nov. 1976 [published July 1977], 44).

1978-The title change of the year-and the South-Will-Rise-Again-Suh Award is given to The Southern Conference Educational Fund for the change from Southern $\mathrm{Pa}$ triot to Southern Struggle (Title Varies, July-Nov. 1977 [published 1978], 44).
1979 _ . . was awarded to Justus Liebigs Annalen der Chemie, which has been around since 1832 (with only three other title changes) and finally decided to start over in 1979 (with no. 1) as Liebigs Annalen der Chemie (Title Varies, May-Sept. 1979, 28)!

1980-The Great Award, Worst of the Worst, also known as the Grand Turkey, goes to a publisher who should have known better: to the United Nations' Educational Scientific and Cultural Organization for changing the UNESCO Bulletin for Libraries to the UNESCO Journal of Information Science, Librarianship, and Archives Administration (Title Varies, Dec. 1980, 38).

1981- . . went to the American Association for the Advancement of Science, in recognition of their help and concern for the cause of universal bibliographic control, and their deliberately stupid, aggressively, militantly, and reliably dumb editorial decision to fly in the face of all reason, and to rename their magazine each year. The award goes to Science 79, to Science 80 , and to Science 81 , and no doubt next year Science 82 (RTSD 1981).

1982 - . . presented to the U.S. Department of the Interior's Bureau of Land Management for changing Our Public Lands to Your Public Lands. Also known as the This Land is Your Land, This Land is My Land award."

1983 - . . presented to the American Society of Civil Engineers for changing sixteen titles all at once. For example, its Construction Division's Journal of the Construction Division changed to Journal of Construction Engineering and Management."

1984 _. . . as well as the Most Fantastic Title Change Award is presented to the Division of Continuing Education at Florida Atlantic University, for the changes that a single publication has gone through since January of this year. Fantasy Newsletter changed in January 1984 to Fantasy Review. It changed again in March to $S F$ and Fantasy Review, when it absorbed Science Fiction and Fantasy Book Review. In April, it changed again to simply Fantasy. Each issue also uses several of these variations in various positions on the publication. ${ }^{\dagger}$

"Supplied by Frank E. Sadowski, Jr., University of Rochester, a past presenter of the Worst Serial Title Change of Year Award

†From the archives of the Worst Serial Title Change of the Year Committee 
1985- . . . also the Incitement to Violence Award to the Center for Women's Policy Studies for: Response to Violence in the Family of Sexual Assault, [which] changed to Response to the Victimization of Women and Children. Since its birth in 1976, it has had four other titles. ${ }^{\dagger}$

1986 _ . . . also the Why Bother to Change the Title Award goes to the Watt Publishing Company for retitling Animal Nutrition o Health as Animal Health \& Nutrition. ${ }^{\dagger}$

1987_ .... or the Multiple Disaster Award, has been earned to Jolin Wiley for again changing the names of all parts of the Journal of Polymer Science, and to add to the disaster, also playing musical chairs with the letter designation of each part.

1988 _... as well as, the Globe Trotter's Award is presented to North American Publishing Co., who decided to go globe trotting after thirty years of stability. Called American Import \& Export Bulletin from 1934 to 1974 , it has had seven title changes since then, six within three years, three of them occurring in 1987 (RTSD $1988,53)$.

1989- ... goes to PSC Publications, which merged the basic and deluxe editions of American Home Arts Needlecraft for Today to form Needle \& Craft. The committee wonders [whether] they were trying to return to their roots since they started as Needle \& Thread (RTSD 1989, 46).

1990 _ . . goes to IEEE for changing the IEEE Journal of Robotics and Automation to IEEE Transactions on Robotics and Automation (ALCTS 1990, 62).
1991 - ... is presented to the Foundation Center for Grants for International and Foreign Programs, which flip-flopped to Grants for Foreign and International Programs for no other reason than to make it impossible to shelve for those of [us] who ...shelve alphabetically (ALCTS 1991, $64)$.

1992- ... goes to Rohrich Press of Akron, Ohio, for changing the Blue Book of Sr. College, University and Junior o Community Athletics to Blue Book of College Athletics for Senior, Junior \& Community Colleges, its third title change in four years. All of the changes have simply stir-fried the same seven or eight words... into new and different "winning" combinations (ALCTS 1992).

1993 - ... goes to Broadcasting and Cable Yearbook. Bowker has had the title for two years and has already published it under two different titles: the [aforementioned] and Broadcasting and Cable Marketplace. For a publication that has had more title changes than we care to discuss, we ask Bowker to pick one and stick with it, please (O’Neill 1993)!

1994 . . . is presented to Barron's for returning to its original title after a brief 52-year experiment as Barron's National Business and Financial Weekly. After 52 years couldn't they have waited for a new volume to make the change (Gordon 1994)? [Author's note: The original title was simply Barron's. In 1994, the title changed from Barron's National Business and Financial Weekly back to Barron's.] 